\title{
Studies on the Effect of Macro and Micro Nutrients on Yield and Nutrient Uptake in Garlic (Allium sativum L.)
}

\author{
Y.R. Shukla, Manisha Kaushal and Priyanka Bijalwan*
}

Department of Vegetable Science, Dr. Y.S. Parmar University of Horticulture and Forestry, Nauni, Solan-173230 (HP), India

*Corresponding author

\section{A B S T R A C T}

\section{Keywords}

Allium sativum, Macro and micro nutrients, Nutrient uptake

Article Info

Accepted:

10 September 2018

Available Online:

10 October 2018
The present investigation entitled "Studies on the effect of macro and micro nutrients on yield and nutrient uptake in garlic (Allium sativum L.)" was conducted during Rabi season of 2015-16 at Horticultural Research and Training Station and KVK, Kandaghat of Dr. Yashwant Singh Parmar University of Horticulture and Forestry, Nauni, Solan. Ten combinations of different macro and micro nutrients were replicated thrice in the form of ten treatments in a plot having dimensions of $2.0 \times 2.0 \mathrm{~m}$. The experiment was laid out in a randomized block design with three replications involving a spacing of $20 \times 10 \mathrm{~cm}$. The cloves of garlic variety 'Kandaghat Selection' were sown on $1^{\text {st }}$ October, 2015. The data were recorded onbulb yield per hectare (q) and NPK uptake by the plant. The results revealed that application of 125 per cent of recommended dose of NPK $+\mathrm{Zn} @ 7.5 \mathrm{~kg} / \mathrm{ha}$ produced best results in terms of bulb yield per hectare (q) and NPK uptake by the plant, whereas, minimum values for all these characters were recorded in the absolute control.

\section{Introduction}

Garlic (Allium sativum L.) is the most widely used cultivated Allium species after onion belongs to the family Amaryllidaceae. Garlic is one of the main Allium vegetable crops known worldwide with respect to its production and economic value. Garlic is cultivated all over India mainly in Gujarat, Orissa, Madhya Pradesh, Rajasthan, Uttar Pradesh and Maharashtra. In the Indian subcontinent, people use fresh leaves of garlic as salad and a tasty pickle is also prepared from its cloves. Garlic has higher nutritive value as compared to other bulbous crops. It is a rich source of carbohydrates $(29.0 \%)$, proteins
$(6.3 \%)$, minerals $(0.3 \%)$, essential oils $(0.1-$ $0.4 \%)$ and also contains appreciable quantities of fats, vitamin $\mathrm{C}$ and sulphur (Memane et al., 2008).

Keeping in view the increasing Indian population and decreased cultivated crop area, there is a need to enhance the production as well as productivity to meet out the vegetable requirement of the country. Modern agriculture largely depends on the use of chemical fertilizers. Reasons for low yield of garlic are mainly depletion of macro and micro nutrients from the soil, use of low yielding varieties with low or no inputs and poor management practices. The use of 
chemical fertilizer helps in achieving maximum yield of the crop (Singh and Tewari, 1968). Both macro and micro nutrients have various roles to play in different soils and their removal by different crops vary with different seasons and areas. In order to improve garlic production, different means of fertilizer application (type, time and rate) are considered to be the limiting factors which should be given due consideration (Brewster and Butler, 1989) and the production of vigorous sprouts is one of the most important factors of successful garlic production through balanced nutrient application (Potgieter, 2006). Bulbous crops are heavy feeder, requiring optimum supplies of nitrogen, phosphorus, potassium, zinc, sulphur and other nutrients which can adversely affect growth, yield and quality of bulbs under sub optimal levels in the soil (Gubb and Tavis, 2002). Mallangouda et al., (1995) were of the opinion that nitrogen, phosphorus and potassium plays an important role in improving vegetative growth and yield of garlic.

Improved management of nitrogen, phosphorus, potassium and other inputs in the soil could improve yield and quality of vegetables and other crops (Nai-hua et al., 1998). Garlic is a long day crop and has special root architecture i.e., shallow root system, low root densities and lack of root hairs, so it needs a high concentration of N, P and $\mathrm{K}$ in the soil solution to satisfy the potential demand. Hence garlic needs high levels of $\mathrm{N}, \mathrm{P}$ and $\mathrm{K}$ in the soil (Brewster, 1994). High yield and good quality of garlic can therefore be obtained through efficient and balanced use of macro and micro nutrients.

\section{Materials and Methods}

'Kandaghat Selection' variety was choosen for the studies. It is a local clonal selection from Himachal Pradesh. The plants are of long day type. Bulbs are creamish white having diameter ranging from $3.5-5.5 \mathrm{~cm}$. Bulbs have 13-16 yellowish white cloves having diameter of $1.1-1.7 \mathrm{~cm}$. The cultivar is suitable for cultivation in Northern hilly regions of India. It is a medium storer and tolerant to common diseases. Average yield per hectare ranges from 140-200 q/ha. The experiment was laid out in randomized block design with three replications and ten treatments. The plot size was taken $2.0 \times 2.0 \mathrm{~m}$ with spacing of $20 \times 10$ $\mathrm{cm}$ and total number of plots was thirty. The soil had 7.11 and 0.40 of $\mathrm{pH}$ and electrical conductivity, respectively. The soil had fertility status of $279.25 \mathrm{~kg}$ nitrogen/ha, 30.25 $\mathrm{kg}$ phosphorus/ka and $355.28 \quad \mathrm{~kg}$ potassium/ha. Annual precipitation of the area is $1120 \mathrm{~mm}$, which is received during monsoon (June- September).

\section{Results and Discussion}

Response of a crop to fertilizer, which is a function of nutrient uptake, is highly variable and depends on crop, type of soil, past use of land, local weather conditions as well as choice of the season. In the present studies (Table 1), application of different combinations of nutrients significantly increased the $\mathrm{N}$ uptake in garlic plant. Maximum nitrogen uptake $(44.49 \mathrm{~kg} / \mathrm{ha})$ was obtained in $\mathrm{T}_{10}$ (125\% of recommended dose of NPK + Zn @ 7.5kg/ha). The data pertaining to phosphorus uptake (Table 1) have been presented which revealed significant effect of different treatments. Maximum phosphorus uptake $(16.47 \mathrm{~kg} / \mathrm{ha})$ was obtained in treatment $\mathrm{T}_{10}(125 \%$ of recommended dose of $\mathrm{NPK}+\mathrm{Zn} @ 7.5 \mathrm{~kg} / \mathrm{ha}$ ). Increasing N uptake with increasing $\mathrm{N}$ fertilizer application to the soil is due to the result of improved availability and uptake through increased root growth and effective absorption same results were also reported by Kumar and Rao (1992), Panda et al., (1995), Nasreen and Hossain (2004) and Tamirat (2006). 
The data (Table 1) showed that there was significant gain in potassium uptake by the use of different combinations of nutrients. Maximum uptake of potassium $(32.93 \mathrm{~kg} / \mathrm{ha})$ was obtained in the treatment $\mathrm{T}_{10}(125 \%$ of recommended dose of NPK + Zn @ 7.5kg/ha). Potassium is a mobile element within the soil having higher moisture content and moves with water to different plant tissues. Potassium has a major role in plant metabolism as it activates some enzymes especially involved in the metabolism of carbohydrates. Under high levels, starch moves efficiently from sites of production to storage. In addition, it plays a potential role in the transport of water and essential nutrients throughout the plant in the xylem (Mansour, 2006). It seems that application of a combination of nutrients (as NPK and $\mathrm{Zn}$ in the present case) might have improved the nutrients uptake of the crop as a result of their cumulative effect on the nutrients uptake by increasing the dry matter production. According to Singh and Dhankar (1989), availability of higher potassium fertilizer could have caused higher uptake of $\mathrm{K}$ and other nutrients by garlic crop which could have increased production of carbohydrates during photosynthesis and this in turn, have increased TSS content of bulbs. Minimum potassium uptake was, however observed in the absolute control $(15.08 \mathrm{~kg} / \mathrm{ha})$ where no nutrients were applied.

Table.1 Effect of different macro and micro nutrients on nitrogen, phosphorus and potassium uptake by garlic plants $(\mathrm{kg} / \mathrm{ha})$

\begin{tabular}{|c|c|c|c|c|c|}
\hline $\begin{array}{l}\text { Treatmen } \\
\text { t Code }\end{array}$ & Treatments & $\begin{array}{l}\text { Bulb } \\
\text { yield } \\
\text { (q/ha) }\end{array}$ & $\begin{array}{c}\text { N } \\
\text { uptake } \\
\text { (kg/ha) }\end{array}$ & $\begin{array}{c}\text { P } \\
\text { uptake } \\
\text { (kg/ha) }\end{array}$ & $\begin{array}{c}\mathrm{K} \\
\text { uptake } \\
\text { (kg/ha) }\end{array}$ \\
\hline $\mathrm{T} 1$ & $\begin{array}{l}\text { Absolute control (No application of macro or micro } \\
\text { nutrients) }\end{array}$ & 138.75 & 19.87 & 6.47 & 15.08 \\
\hline $\mathrm{T} 2$ & $75 \%$ of recommended dose of NPK. & 158.25 & 23.90 & 8.39 & 18.77 \\
\hline T3 & $75 \%$ of recommended dose of NPK + Zn @ $5 \mathrm{Kg} / \mathrm{ha}$. & 162.38 & 25.61 & 9.23 & 20.10 \\
\hline T4 & $75 \%$ of recommended dose of NPK+Zn @ $7.5 \mathrm{Kg} / \mathrm{ha}$. & 170.25 & 26.30 & 9.82 & 21.01 \\
\hline T5 & Recommended dose of NPK (100 \% NPK).* & 176.63 & 31.41 & 11.19 & 23.35 \\
\hline T6 & Recommended dose of NPK+Zn @ 5 Kg/ha. & 182.40 & 33.37 & 12.09 & 25.02 \\
\hline $\mathrm{T} 7$ & Recommended dose of NPK+Zn@7.5 Kg/ha. & 187.88 & 34.58 & 12.80 & 26.45 \\
\hline $\mathrm{T} 8$ & $125 \%$ of recommended dose of NPK. & 190.58 & 40.05 & 14.85 & 29.89 \\
\hline T9 & $125 \%$ of recommended dose of $\mathrm{NPK}+\mathrm{Zn} @ 5 \mathrm{Kg} / \mathrm{ha}$. & 192.75 & 42.63 & 15.82 & 31.44 \\
\hline $\mathrm{T} 10$ & $\begin{array}{l}125 \% \text { of recommended dose of NPK+ Zn @ } 7.5 \\
\mathrm{Kg} / \mathrm{ha} .\end{array}$ & 197.25 & 44.49 & 16.47 & 32.93 \\
\hline $\mathrm{CD}_{(0.05)}$ & & 19.91 & 1.67 & 0.83 & 0.93 \\
\hline
\end{tabular}

The yield per plot was calculated by weighing all the marketable bulbs in a plot and was multiplied with a suitable factor to work out yield per hectare. In the present studies (Table 1), per hectare yield ranged from $138.75 \mathrm{q} /$ ha (control plot) to $197.25 \mathrm{q} / \mathrm{ha}$ in treatment $\mathrm{T}_{10}$ (125\% recommended dose of NPK + Zn @ $7.5 \mathrm{~kg} / \mathrm{ha})$ which was 29.65 per cent more.
The treatment which produced maximum yield i.e. $\mathrm{T}_{10}$. Assefa et al., (2015) who also reported increased yield due to the application of $\mathrm{N}, \mathrm{P}, \mathrm{S}$ and $\mathrm{Zn}$, possibly due to the combined effect of contribution of $\mathrm{N}$ to chlorophyll, enzymes and protein synthesis, as $\mathrm{P}$ is essential for root growth, phosphoproteins and phospho-lipids. 


\section{References}

Assefa, A.G., Mesgina, S.H. and Abrha, Y.W. 2015. Effect of inorganic and organic fertilizers on the growth and yield of garlic crop in northern Ethiopia. Journal of Agricultural Science. 7(4): 80-86.

Brewster, J.K. and Bulter, H.A. 1989. Effect of nitrogen supply on bulb development in onion. Journal of Experimental Botany.40: 1155-62.

Brewster, J.L. 1994. Onion and other vegetable. In: Allium.UK: CABI. 236p.

Gubb, I.R. and Tavis, M.S. H. 2002. Onion pre harvest and post-harvest considerations. In: H.D. Rabinowitch and L. Currah (eds.). Allium Crop Science, CABI. pp. 237-50.

Kumar, K. and Rao, K.V.P. 1992. N and P requirement of upland rice in Manipur. Indian Journal of Agronomy. 29: 30649.

Mallangouda. B., Sulikeri, G.S., Hulamari, W.S., Murthy, B.G. and Madalgeri, B.B. 1995. Effect of NPK and FYM on growth parameters of onion, garlic and coriander. Current Research University of Agricultural Science. 24(11): 212-13.

Mansour FYO. 2006. Physiological studies on garlic (Allium sativum L.). M.Sc. Thesis, Faculty of Agriculture, Minufiya University, Egypt.

Memane, P.G., Tomer, R.S., Kulkarni, G.U. and Chovatia, R.S. 2008. Effect of clove weight and plant growth regulators on growth and yield of garlic (Allium sativum L.) cv. Gujarat Garlic 3.The Asian Journal of Horticulture. 3(1): 8286.
Nai-hua, Y., Dingguo, Z. and Wang, J. 1998. Phosphorus and potassium nutrient management for vegetable soils in Shanghai and Guangdong. In: Donald L. Armstrong (Ed.), Better Crops International. 12(1): 7-9.

Nasreen, S. and Hossain, A.K.M. 2004.Nutrient uptake and yield of onion as influenced by chemical fertilizer and organic manure. Indian Journal of Agricultural Research. 38(3): 164-70.

Panda, S.C., Panda, P.C.P. and Nanda, S.S. 1995. Nitrogen and phosphorus uptake from Tithonia diversifolia and inorganic fertilizers and their effect on maize yield in Malawi. 264-266 p. In: proceeding of symposium on maize production technology for the future. Challenge and opportunities in Africa AA, Ethiopia 21-25 September 1998. CIMMYT and EARO.

Potgieter, J. 2006. Verbal communication on macro elements application time. Researcher, Limpopo. Department of Agriculture.

Singh, J. and Dhankhar, B.S. 1989. Effect of nitrogen, potash and zinc on growth, yield and quality of onion. Indian Agriculture. 32(3):163-70.

Singh, J.R. and Tewari, J. 1968. Effect of source of organic manures and levels of nitrogen on growth characteristics of garlic (Allium sativum L.). Indian Journal of Horticulture. 25:191-95.

Tamirat, T. 2006. Effect of $\mathrm{N}$ and $\mathrm{P}$ application on seed yield and nutrient uptake of onion on black soil of Agarfa, south eastern highlands of Ethiopia. M.Sc. thesis, Haryana University, Ethiopia. pp. 47-65.

\section{How to cite this article:}

Shukla, Y.R., Manisha Kaushal and Priyanka Bijalwan. 2018. Studies on the Effect of Macro and Micro Nutrients on Yield and Nutrient Uptake in Garlic (Allium sativum L.). Int.J.Curr.Microbiol.App.Sci. 7(10): 1201-1204. doi: https://doi.org/10.20546/ijcmas.2018.710.133 